\title{
Journalism Education and Children's Rights: New Approaches to Media Development in CEE/CIS Countries
}

\author{
Michael Foley \\ Technological University Dublin, michael.foley@tudublin.ie \\ Noirin Hayes \\ Technological University Dublin, noirin.hayes@tudublin.ie \\ Brian O'Neill \\ Technological University Dublin, brian.oneill@tudublin.ie
}

Follow this and additional works at: https://arrow.tudublin.ie/aaschmedart

Part of the Communication Commons

\section{Recommended Citation \\ Journalism Education and Children's Rights: New Approaches to Media Development in CEE/CIS Countries Michael Foley, Noirin Hayes and Brian O'Neill Irish Studies in International Affairs, Vol. 23 (2012), 1-12. Published by the Royal Irish Academy DOI:10.3318/ISIA.2012.23.47}

This Article is brought to you for free and open access by the School of Media at ARROW@TU Dublin. It has been accepted for inclusion in Articles by an authorized administrator of ARROW@TU Dublin. For more information, please contact arrow.admin@tudublin.ie, aisling.coyne@tudublin.ie,gerard.connolly@tudublin.ie.

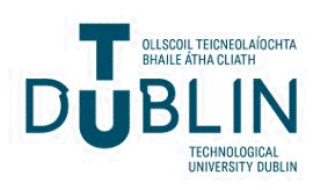




\title{
Journalism Education and Children's Rights: New Approaches to Media Development in CEE/CIS Countries*
}

\author{
Michael Foley, Nóirín Hayes and Brian O’Neill
}

Dublin Institute of Technology

\begin{abstract}
In 2008, Dublin Institute of Technology and UNICEF collaborated in the development of a unique approach to journalism education in Central and Eastern Europe (CEE) and the Commonwealth of Independent States (CIS) regions. Universities in Turkey, Romania, Georgia, Macedonia, Serbia, Azerbaijan and Kyrgyzstan in partnership introduced a new child-rights syllabus into their respective journalism programmes. Instead of the traditional approach of providing limited training to professional journalists on the United Nations Convention on the Rights of the Child (UNCRC), the objective of this initiative - entitled Child Rights and Journalism Practice-has been to embed at source the concept of children's rights with a view to enhancing overall standards in journalism. The media in the CEE/CIS countries have a quite different history to other parts of the world, and the tradition of an independent, responsible media as a fourth pillar of democracy is virtually non-existent. It has effectively been a mouthpiece of government, offering no challenge to the status quo. Largely characterised by an absence of informed, serious discourse, poor standards in journalism reflect the parlous state of civil society as a whole. By focusing on journalism in the context of the academy and raising awareness of children's rights from a journalistic perspective, the project seeks to provide a relatively safe space for critical engagement with journalistic ethics and values. Children are targets of, or are implicated in, nearly all aspects of public policy, yet are largely invisible in news-media coverage, and rarely have their voices heard in matters affecting them. By using the UNCRC as both a lens for critically reflecting on media coverage and representation of children, and as a platform for developing a civic journalism that might otherwise be difficult, the project promotes improved media standards and a greater awareness among students, educators and media professionals of human-rights

\footnotetext{
*This article is based on a presentation to the annual conference of the Committee for International Affairs, entitled 'Democratisation and the New Media', which took place at the Royal Irish Academy, Dublin, 25 November 2011.
}

Authors' e-mails: mfoley@ireland.com; noirin.hayes@dit.ie; brian.oneill@dit.ie

Irish Studies in International Affairs, Vol. 23 (2012), 1-12.

doi: 10.3318/ISIA.2012.23.06 
protection. A particular feature of the programme has been the use of new media both in the delivery of training and as an opportunity for building alternative journalism platforms, ensuring that journalism education is integral to the changing media landscape of the countries concerned.

\section{INTRODUCTION}

Media assistance to the former communist countries of Eastern Europe from 1989 became an important part of the transformation of that part of Europe from a socialist command economy to a democratic, liberal market economy. The media was seen as an important ideological weapon of the previous regimes, and so was to be transformed in order to change society.

The exact amount of media aid is unknown, as much of it was hidden beneath such headings as 'aid to civil society' and 'democracy-building', but it is known to have accounted for hundreds of millions of euros. Most of this funding was spent on specific training of working journalists, some was used to establish codes of conduct or to help legislators frame media laws, and some was in the form of loans to help establish new media enterprises.

In 2008, the UN agency responsible for the welfare of children, UNICEF, commissioned the School of Media at Dublin Institute of Technology (DIT) to develop a project that would engage journalism faculties across the CEE and CIS countries in order to encourage capacity building in the area of journalism and children's rights. The DIT team had previously worked with the BBC World Service Trust in a number of projects in the Balkans and Ukraine. We accepted the commission because the approach coincided with our view that the traditional training model for media development had not worked, and that what was needed, if media was to make a worthwhile contribution to governance and the development of democracy, was a greater emphasis on the education of journalism students in order that ethics and values would be inculcated from an early stage in their development as journalists. Teaching journalism practice within a context of children's rights seemed to offer an interesting and original opportunity to explore issues relating to ethics and democracy. Discussing children's issues, it later emerged, offered a 'safe space' to discuss wider issues relating to human rights and democracy building.

\section{JOURNALISM AND THE PUBLIC SPHERE}

The connection between a functioning free press and democracy can be traced to arguments espoused in the seventeenth century by John Milton in Areopagitica, his treatise on censorship, and to Thomas Jefferson's well-known comment on press freedom:

The basis of our governments being the opinion of the people, the very first object should be to keep that right; and were it left to me to decide whether we should have a government without newspapers or newspapers without a government, I should not hesitate a moment to prefer the latter. ${ }^{1}$

Later proponents of a free press included James Mill, in his Liberty of the press (1821), Jeremy Bentham, in Liberty of the press and public discussion (1820), and J.S. Mill, in On liberty (1859).

${ }^{1}$ Jefferson to Edward Carrington (1787), quoted in John Keane, Media and democracy (London, 1991), 2. 
Jürgen Habermas, in his Structural transformation of the public sphere, argued that a close relationship existed in the early years of democratic development - in the eighteenth century - between newspapers, magazines and journals and the sphere where debates and analyses took place, and that this transformed Europe from a representational culture to an Öffentlichkeit, or public sphere, or from a passive culture to one where citizens took an active role in society. ${ }^{2}$ He was critical, of course, of modern mass media because it again encouraged a passive culture. Journalists have tended to draw on Habermas, and often talk of creating a public sphere through media development. However, Habermas is not without his critics: for instance, John Keane, one of the foremost thinkers on democracy, in his classic Media and democracy (1991) dismisses Habermas as harbouring 'a certain nostalgia for the heroic ideals of the early modern public sphere'.

The intellectual tradition of defending liberty of the press is important to modern journalism. The argument that journalism is central to democracy comes directly from Milton and Locke, through Jefferson, to the first amendment of the American Constitution, and has been accepted by judicial courts on both sides of the Atlantic. According to the liberal theory of the press, it operates under a 'free press' model whereby anyone is free to publish a newspaper or magazine without having to be licensed by state authorities. Indeed, for Bill Kovach and Tom Rosenstiel, in The elements of journalism, journalism owes its first loyalty to citizens, and owes no loyalty to any state authority, its primary purpose being to provide citizens 'with the information they need to be free and self-governing'. ${ }^{4}$ Marie McGonagle's 1996 work, A textbook on media law, details a number of rulings of the European Court of Human Rights regarding the role of the journalist-for instance, that the journalist is to be a watchdog on behalf of the public, and that a journalist's role is central to the workings of democracy. ${ }^{5}$

The link between journalism and democracy is, of course, the main reason for media development. The Nobel Prize-winning economist Amartya Sen argues that for people to develop their full potential they need freedom, and freedom of speech is one of the freedoms required for human development: 'To express publicly what we value and to demand that attention be paid to it, we need free speech and democratic choice'. ${ }^{6}$ Jesper Strömbeck says there are four theoretical models of democracy: procedural democracy (free and fair elections), competitive elections, participatory democracy (citizen participation) and deliberative democracy (discussions among the public and their representatives). ${ }^{7}$ The first and second models are based on the election of representatives, whereas the third and fourth depend on more direct forms of citizen participation; however, all four depend on journalism. In the first and second theoretical models, the journalist plays the classic role of watchdog, or the fourth estate; in the third and fourth models, the citizens have more room to speak for themselves, but the journalist still plays a key role, because 1962]).

${ }^{2}$ Jürgen Habermas, Structural transformation of the public sphere (Cambridge, 1992 [orig.

${ }^{3}$ Keane, Media and democracy, 35.

${ }^{4}$ Bill Kovach and Tom Rosenstiel, The elements of journalism: what newspeople should know and the public should expect (London, 2003), 4.

${ }^{5}$ Marie McGonagle, A textbook on media law (Dublin, 1996), 34, 94, 255, 258.

${ }^{6}$ Amartya Sen, Development as freedom (Oxford, 1999), 152.

${ }^{7}$ Jesper Strömbeck, 'In search of a standard: four models of democracy and their normative implications for journalism', Journalism Studies 6 (3) (2005), 331-45: 340. 
'democracy can never become more deliberative without the active participation of media and journalism'. ${ }^{8}$

If a clear relationship had been established during the past two hundred years between democracy, journalism and the press, it was evident that if journalists and journalism claimed to exercise a role that was supported by rights, philosophy and law, there was, then, a clear link with children's rights, which were formulated in the UNCRC in 1989 (192 states were party to the convention, with only the US and Somalia failing to ratify it). The rights of freedom of expression and freedom of speech gave journalism its moral force, and children - as now agreed with near unanimity by governments throughout the world - also had specific rights, and journalists, on behalf of the public, had a role of watchdog regarding the actions of government.

\section{MEDIA DEVELOPMENT IN THE CEE/CIS COUNTRIES}

Media development had taken place in the CEE/CIS countries since the fall of communism-whether it had worked or not is a moot point. There were also those who argued as to whether it should have taken place at all. James Carey, one of the most respected journalism academics, said in 1991:

For the past year or more American journalists and intellectuals have been travelling east in order to teach these newly liberated peoples the practical arts of writing a First Amendment, managing a modern newspaper or television station, or, more elementary yet, writing and editing Western-style journalism. We regularly assume these days that we have something to export to the peoples of Eastern Europe. We are less open to the thought that we might have something to learn from them, that they might teach us something about democracy and civic culture. ${ }^{9}$

Journalism education in the CEE/CIS countries had a very different history to that of the West. As Peter Gross points out, following the ascent to power of communist parties in the 1940s, 'journalism education was defined as political education and coupled with propagandistic techniques to be applied both in print and broadcast media'. ${ }^{10}$ Gross, in common with other writers, describes the highly theoretical nature of Eastern European and Soviet journalism education, and also the highly propagandist nature of the curriculum. ${ }^{11}$

Colin Sparks summed up the role of the communist journalist and how it differed from that of the Western journalist thus:

Journalism did not make the same claims to objectivity and fairness which, it is said, characterise the Western media, and in particular those of the USA. On the contrary, the function of journalists was to explain and to educate and to help by their writing to win support for the construction of the new socialist world. ${ }^{12}$

${ }^{8}$ Strombeck, 'In search of a standard', 340.

'James Carey, 'A republic, if you can keep it' in Eve Stryker Munson and Catherine A. Warren (eds.), James Carey: a critical reader (London, 1997), 207-27: 210.

${ }^{10}$ Peter Gross, 'Before, during, and after: journalism education' in Jerome Aumente, Peter Gross, Ray Hiebert, Owen Johnson and Dean Mills (eds.), Eastern European journalism: before, during and after communism (New York, 1999), 147-80: 148.

${ }^{11}$ Peter Gross, 'Albania', in Ray Eldon Hiebert, Peter Gross, Dean Mills, Timothy Kenny and Maurice Fliess, Looking to the future: a survey of journalism education in Central and Eastern Europe and the former Soviet Union (Arlington VA, 1994), 4.

${ }^{12}$ Colin Sparks Communism, capitalism and the mass media (London, 1998), 43. 
The media in the CEE/CIS countries had a very different history from other parts of the world. It had effectively been a mouthpiece of government offering little challenge to the status quo, and characterised by an absence of informed, serious discourse. Following the collapse of the Soviet Union in 1991, journalism education reflected an ideological perspective that had ceased to match reality. For years, the approach to training journalists in children's rights in the CEE/CIS countries had been like much media development in the regions in general: a quantitative one, with a few practising journalists receiving some training here and there. The focus tended to be on specific aspects of children's rights rather than on the rights of children. This has produced very limited results in terms of the representation of children or children's issues in the media. Media development is hardly a core activity of UNICEF, so it was unclear if it had concluded that a training model of media development had failed, though it must be said that the organisation appeared to be pragmatic, noting its own investment and the lack of impact.

There has been criticism of media development; for instance, research by the Media Map Project, the two-year research project carried out by Internews and the World Bank Institute, stated:

The international development community needs to spend less time training journalists and more time on efforts to build country level leadership for a strong and independent media as a key institution of development. ${ }^{13}$

In 2008, Peter Gross, writing about Romania, which by then had joined the EU, said of the media:

It is hardly a surprise that despite showing promise more than once since 1989 that they might evolve as bona fide platforms for news, information, and varied opinions, most news media outlets persist being organs of disinformation, misinformation, intimidation, trivialization, rumours, advocacy, and propaganda on all political and economic issues or those tinged by them. ${ }^{14}$

Why has so much activity and money failed to put in place a responsible media that can contribute to the development and strengthening of democracy? According to Ognianova:

(a) most training sessions have been too short, (b) they have been too theoretical and general, and (c) they have insulted the participants by revealing the visitors' complete ignorance about their countries and by preaching the 'ABCs' of journalism to experienced professionals. ${ }^{15}$

Most training has been offered by development agencies, including those funded by USAID (United States Agency for International Development), the EU and others. Much of it has been vocational and skills-based, and many of the trainers have been working journalists, consultants and trainers rather than educators. However, most trainers employed by these agencies have never tried to find or develop a journalistic voice from within the countries they are working in because they are charged with promoting Western journalistic

\footnotetext{
${ }^{13}$ Mark Nelson with Tara Susman-Peña, Rethinking media development: a report on the Media Map Project (2011), 5, http://www.mediamapresource.org/research-and-resources (accessed 1 July 2012).

${ }^{14}$ Peter Gross, 'Forward to the past: the intractable problems of Romania's media system', International Journal of Press/Politics 13 (2) (2008), 146.

${ }^{15}$ Ekaterina Ognianova, 'Farewell to parachute professors in East-Central Europe', Journalism \& Mass Communication Educator 50 (1) (1995), 34-47: 36.
} 
practices. They rarely speak the local language, have little understanding of local journalism or its history, and often have poor knowledge of the political context within which the people they are training work. What is being taught is primarily based on the British and US models - a cross between the New York Times and the $\mathrm{BBC}$ but presented in idealised form, as Sparks has suggested. ${ }^{16}$

John C. Merrill voiced a concern that was otherwise unstated, that the insistence that the media everywhere conform to Western 'capitalistic and pluralistic' media structures was

not only an arrogant and ethnocentric one but also betrays a stultified, intellectual view of reality. Cultures are different; the values that shore up such cultures are different. Stages of national development are different, citizens' expectations are different. ${ }^{17}$

There are other problems associated with the training and vocational model that has predominated in the CEE and CIS regions since the collapse of communism. This model has encouraged some of the brightest and best to go abroad, since they believe they have been trained up to something called 'Western standards'. Sadly, many want to work elsewhere not so much to bring Western media skills to, for example, Uzbekistan but to work abroad. Other journalists - some having availed of scholarship schemes to do journalism master's degrees in the US - believe they are too highly trained to work as journalists for low pay, and seek donor money to offer yet more training, or work in Western-financed media centres or media-development centres whose sole function is to access Western donor funding and offer Anglo-Saxon or Western journalism training. Vocational training can also give a spurious authority to media output. Eastern and South-eastern Europe have many radio stations, television stations, magazines and newspapers with very high production values that disguise and even give authority to bad journalism.

\section{PARTNERING WITH UNIVERSITIES}

Universities are publicly funded bodies designed to be repositories of culture. They also inform the same culture and interpret it. If journalism rests on values of truth, accuracy and verification-values informing its story-telling and informing of the public - the inculcation of those values should take place within an intellectual context that will allow a new journalistic voice to emerge - one shaped by those values. Western journalism schools can provide one side of the partnership - teaching skills, curriculum development, establishing contacts-universities as public trustees can ensure the specific cultural relevance of international initiatives, with journalism education acting as part of a broader process of educational and cultural exchange.

There is a long tradition of journalism education in the universities of the CEE/CIS regions, going back to the formation of the School of Journalism at Moscow State University in 1947. Such universities have been dismissed by Western media-development agencies as unreconstructed Stalinism at worst, or, at best, offering an out-of-date model that is incapable of reform. The tradition of centralisation was a major feature in all curriculum matters in such universities, and topics such as media coverage or contact with the media were normally forbidden.

\footnotetext{
${ }^{16}$ Sparks, Communism, capitalism and the mass media, 176.

${ }^{17} \mathrm{John}$ C. Merrill, 'Obstacles to the professionalization of mass media in post-Soviet Central Asia: a case study of Uzbekistan', Journalism Studies 4 (1) (2003), 91-103: 93.
} 
In the years immediately following the fall of communism, there were many offers of university partnerships, but most US universities preferred not to deal with existing universities in the CEE/CIS regions, opting instead to establish their own institutions. This lack of contact was especially true of journalism faculties, given the former ideological importance of journalism to the former regimes. The University of Missouri, for example, established the American University in Bulgaria. Rutgers, the State University of New Jersey, opened its Media Resource Center in Warsaw (though it was later plagued with problems, and lost its US funding). New York University founded the Russian-American Press and Information Center, now the Press Development Institute, which focused on print-journalism training, growing in time to nineteen field offices, though of uneven quality. ${ }^{18}$

In most countries in the CEE/CIS regions, there are US universities offering US syllabi usually validated by US universities. These universities can be found right across the regions, from Central Asia to the Balkans, from Bishkek in Kyrgyzstan to Sofia in Bulgaria. Some contacts had been made with Eastern and South-eastern European universities through US Fulbright programmes and EU-funded university exchange-and-links programmes, especially the EU's Tempus programme. Most of these links were channelled through already existing university programmes rather than through media programmes.

Staff at DIT had been involved in journalism education and training in transitional democracies since the mid-1990s. We understood and had experience of the issues raised by Ognianova, Merrill and Gross. Following involvement in an EU PHARE project in Bulgaria and in a Tempus project in Ukraine - both in partnership with the BBC World Service Trust and both university-based journalism projects-lessons were learnt that suggested an alternative to the existing training model for professionalising and strengthening journalism in the transitional democracies.

As journalism schools in Western Europe embraced a theoretical perspective, they sought to produce reflective journalism practitioners: young journalists who would argue for a better way because they were well trained and educated, journalists who had absorbed the tested way of doing things but were now in a position to suggest alternatives. They would be trained to be critical and to ask questions, not just of the political or economic system but also of their own profession. Critically-aware journalists were desperately needed in transitional democracies, and only universities could produce them.

Universities in transitional democracies can operate in partnership with their Western European counterparts because there are academic traditions of exchanges, conferences and other links already in place. The university can educate large numbers of young journalists who will eventually be the majority, or at least a sizeable minority, of journalists in a particular country.

\section{REPORTING ON CHILDREN'S RIGHTS}

Issues concerning children and the coverage of stories relating to childhood have been debated within journalism, though the following view expressed by journalist Kelly McBride of the Poynter Institute is probably the more commonly held attitude:

As a young reporter, I dreaded any feature assignment that meant writing about children. My aversion was rooted in two false presumptions. First,

${ }^{18}$ Ellen Hume, The media missionaries: American support for journalism excellence and press freedom around the globe (Miami, FL, 2004), 33. 
I assumed that stories about children were puff pieces just like cute animal features. And when my editors assigned me these pieces I interpreted it as commentary on my ability to report news. I never volunteered to write about children, because I thought it was a fast track to being pegged as something other than the hard-hitting, assertive journalist I wanted to be. Secondly, I thought children were impossible to write about, mainly because they are so hard to quote. They speak in one-word answers and nonsense sentences. They offer up so little. Meaningful information must be dragged out of children in tortuous interviews ... ${ }^{19}$

Concern about children in mainstream journalism debates can probably be dated to a report from the International Federation of Journalists (IFJ) in 1997 that highlighted the absence of children from the vocational training for most media professionals. ${ }^{20}$ The emphasis of journalism education has traditionally been on providing trainee journalists with adaptable skills to enable them to survive in a fast-changing work environment. Children rarely feature other than as part of training in media law in relation to coverage of children at risk, or as subjects of feature material. Various efforts have been made to address this gap, including the establishment of short training schemes, among them those initiated by UNICEF and other NGOs and child-rights agencies. The IFJ itself has been to the fore in raising awareness of the role that journalists can play in promoting human rights, and in calling attention to the plight of children worldwide. Its 1997 survey of codes of conduct found that few mentioned children in the context of ethical issues or dilemmas for journalists. Nevertheless, there are notable exceptions, and most professional media organisations have in the meantime developed guidelines for the coverage of children in the news, as well as advocating child-protection policies and promoting a sense of ethical responsibility on the part of the journalist towards children as subjects. The IFJ's own guidelines seek to embed the principles of children's rights in journalism practice by insisting on a sense of responsibility towards children and respect for their independent rights as citizens. Acknowledging that awareness of the actual detail of the UNCRC was almost entirely non-existent for all but specialists in the area, the IFJ also encouraged media organisations to consider appointing specialised childhood correspondents to keep in touch with policy and legislation in the area.

Unquestionably, the UNCRC underpins this impetus towards greater media awareness of children as rights holders. The convention of 1989-which provided a separate articulation of the rights of the child - is the first legally binding international instrument to incorporate the full range of human rights. With so many countries having signed the convention, for journalists the actions of government, the accountability process and reporting procedures where children's rights were concerned were now to be considered in the context of the political agenda. That the UNCRC had been ratified by every country except Somalia and the US meant children's rights should have become a

\footnotetext{
${ }^{19}$ Kelly McBride, 'Beyond puff: writing about kids', Poynter Institute (Florida, 2003), http:// www.poynter.org/latest-news/everyday-ethics/poynter-ethics-journal/17374/beyond-puff-writingabout-kids/\#.T7WBwrGtfM4.mailto (accessed 2 July 2012).

${ }^{20}$ Mike Jempson and Bill Norris 'Information and child rights: the challenge of media engagement', International Federation of Journalists for PressWise Trust, http://www.mediawise. org.uk/www.mediawise.org.uk/display_pagefb68.html?id = 127 (accessed 2 July 2012).
} 
concern of journalists everywhere, and they should view the monitoring of government and the coverage of any lapses as simply good journalism.

The UNCRC reflects a new vision of the child and childhood. Children are neither the property of their parents nor the helpless objects of charity. They are human beings and the subject of their own rights. The convention offers a vision of the child as a strong, competent individual, and as a member of a family and community with rights and responsibilities appropriate to his or her age and stage of development. By recognising children's rights in this way, the convention firmly sets the focus on the whole child.

The creation of a body of rights for children, the question of what these rights amount to, and how they can best be realised continues to be contested. ${ }^{21}$ Promotion of children's rights is based in part on the recognition that awareness of children's vulnerability and their corresponding need of special protection has not prevented them from suffering as a consequence of decisions made in the adult world. Compassion for the plight of children has often led to them being viewed as an undifferentiated collective, and their being treated as objects of charity rather than as individual human beings with their own strengths and abilities, their own needs and rights; consequently, the issues surrounding children have frequently been deemed non-political, and often have not been addressed. The basic principle of the rights of the child is that society has an obligation to satisfy the fundamental needs of children and to provide assistance for the development of children's personalities, talents and abilities.

The creation of a convention on the rights of the child reflects a generally accepted rule that the greater the awareness of rights, the more chance there is of securing them. It is in this context that the role of journalism is crucially important. The UNCRC itself pays particular attention to the role of the media in children's lives. Article 17 acknowledges the important function performed by the mass media, and encourages media organisations to disseminate information of social and cultural benefit to the child, and to develop appropriate guidelines for 'the protection of children from information and material injurious to his or her well-being' ${ }^{22}$

Notwithstanding the role that journalists can play in mobilising support for the rights of children, or by acting as watchdogs for the public interest, media professionals are not advocates for any agency or specialists in children's rights. Their role is to report accurately. The objective of this project is that, in so doing, they have an awareness of the fundamental rights of the child. Also, we can go back to the idea of the journalists as watchdog. If governments sign and ratify a convention, they can then be held accountable, but it is necessary for journalists to understand what governments are being held accountable to - in this case, the UNCRC. The programme as developed by the team at DIT has the objective of embedding at source the concept of children's rights so that children's rights become a vehicle through which journalism students learn about a whole range of professional and theoretical issues-from ethics, to media regulation, to accountability, to use of sources - whilst acquiring skills in developing story ideas. At the same time, they develop an understanding of human rights, the role of the journalist in society, and the ability to analyse media itself.

${ }^{21}$ James Griffin, On human rights (Oxford, 2008), 94-5.

${ }^{22}$ UNICEF, 'Convention on the Rights of the Child', http://www2.ohchr.org/english/law/crc. htm (accessed 2 July 2012). 


\section{IMPLEMENTING THE PROGRAMME}

If journalism standards have fared so poorly overall in the transition countries of the former communist countries of the CEE and CIS, what then of the situation for children in the media and children's rights? Visibility of children's issues as well as barriers to participation were highlighted by the Young People's Media Network in Europe and Central Asia as particular areas of concern for countries in the region, as illustrated by the following observations:

The media in Macedonia are generally focused on political and economical issues in the country. The social and community issues are not covered enough or at all. The youth issues in Macedonia often are seen from educational or criminal perspectives. We need to make bridges of communication between youth of the region, help to overcome the prejudices and taboos, and to create close relations between young people, no matter of the state borders. (Antoaneta Ivanova, 23, Macedonia)

Young people's interests are not covered widely in Kyrgyzstan. There are only two or three youth TV programmes on Kyrgyz TV. TV channels are not interested in non-commercial programmes. It would be much better if we have more TV youth programmes, more youth media organizations; because there is no other one, besides our Children's Media Center in Bishkek. It would be very good if youth have more youth newspapers. Maybe YPMN will help us; the participants will share their experiences. (Children's Media Center, Bishkek, Kyrgyzstan) $)^{23}$

Sensationalist media coverage of children in difficult circumstances, with little respect for their rights or welfare, is commonplace. Typically, news coverage follows the pattern of stereotyping found globally; for example, the Media Monitoring Project in South Africa found the following:

- Children are under-represented in the news media;

- Children are predominantly represented as victims;

- Children are represented mostly in negative stories;

- Male and female children are equitably represented but are still stereotyped. ${ }^{24}$

It is against this background that the DIT project set out to provide an academic context for education in children's rights and journalism that would both address a theoretical understanding of human-rights issues as they relate to children, and provide a foundation for a journalism practice that is informed by an understanding of rights and their abuses. ${ }^{25}$ The project's target group is journalism students attending journalism faculties throughout the CEE/CIS regions. Central to the project is the delivery of a stand-alone module designed to be at the heart of the curriculum, incorporating a textbook developed at DIT but which has been tailored to suit each country, a teachers' handbook, online teaching, and a student-centred pedagogical methodology. The material has been translated into a number of languages, most notably Turkish and Russian.

${ }^{23}$ Young People's Media Network in Europe and Central Asia: http://www.unicef.org/magic/ bank/case025.html (accessed 2 July 2012).

${ }^{24}$ Media Monitoring Project, 'Children's views on the news', http://www.mediamonitoringafrica.org/images/uploads/empowerchildren.pdf (accessed 2 July 2012).

${ }^{25}$ Michael Foley, Nóirín Hayes and Brian O’Neill, Children's rights and journalism practice: a rights-based perspective (Dublin, 2008). 
Specific sections cover interviewing skills, human rights, child rights, children in conflict, anonymity and identity protection, and sources.

Many countries in the region have hardly developed democratic cultures. Most score badly on the various press-freedom indexes. There is strong evidence that journalists have little understanding of their role in society, and where they offer a critical analysis of society they suffer harassment, imprisonment and even violence and death. In this context, children's issues may seem less contentious than they might otherwise be, and they may be considered to be safer than more overtly politicised topics. Yet all the key elements of contemporary political life impact on children, from finance and economics to social policies and legislation. In this way, reporting more-difficult or politically sensitive topics from a child-rights perspective may provide opportunities to touch on subjects or to enter areas of political debate that might not otherwise be possible. There are opportunities in the area of children's rights also for civic journalism, whereby journalists abandon the notion that they are spectators in political or social processes, and become active participants. This approach has had a significant impact in, for instance, Brazil, involving the work of the NGO news organisation ANDI (Agência de Notícias dos Direitos da Infância [News Agency for Children's Rights]). ${ }^{26}$ In either case, the overall objective is to ensure that journalists armed with an awareness of children's rights are best positioned to monitor and call attention to abuses, to make progress in areas where the integrity of the child is in question, to promote the participation of children in public life and their protection from all forms of abuse, and to raise awareness about children's rights in relation to all issues, policies and practices.

So far, universities in eleven countries have adopted the syllabus and received training in implementing it: Turkey, Georgia, Macedonia, Romania, Azerbaijan, Serbia, Montenegro, Kyrgyzstan, Uzbekistan, Kazakhstan and Mozambique. Interest has been shown by a number of universities in Southern Africa, West Africa and South-east Asia. The programme defines as its learning outcomes students not only gaining an understanding of children's rights as articulated in the UNCRC but being able to apply this knowledge through accurate and fair reporting in keeping with the principles of children's rights and through critical reflection on journalistic codes of practice as they apply to children in the news.

The long-term impact of this initiative will take time to assess, and the programme is currently being externally evaluated. However, local evaluations have provided anecdotal evidence that students are responding positively to the module, and are more likely now to consider stories from perspectives that include children. The Child Rights and Journalism Practice project also embodies a number of ambitious longer-term goals: by focusing on journalism in the context of the academy and by raising awareness of children's rights from a journalistic perspective, the project seeks to provide a relatively safe space for critical engagement with journalistic ethics and values; in this way, the UNCRC can be used as both a lens for critical examination of media coverage and representation of children, and as a platform for developing a civic journalism that might otherwise be difficult. Ultimately, it is an ambition of the project to promote improved media standards and a greater awareness of human-rights protection among students, educators and media professionals. Pedagogy is

${ }^{26} \mathrm{ANDI}$ (http://www.andi.org.br/), a civil-society organisation based in Brazil, was established in 1990 to promote and strengthen dialogue between news organisations and communications/ journalism schools on the subject of communication rights for children. 
central to this: by adopting a transformative pedagogical approach, participants engage in a process of learning that enables them to question and critically reflect on the social contexts in which they operate. ${ }^{27} \mathrm{New}$ media also facilitate this approach to learning and media development. In many of the countries concerned, digital technologies have radically transformed the power structure both within the academy and the wider media world, enabling less-hierarchical and more-democratic teaching styles to emerge in parallel with the alternative journalism platforms that are having such a transformative effect on the media landscape generally.

\section{CONCLUSION}

Events in Western Europe within the media have shown how difficult it is to inculcate values and standards in journalism: for instance, the British government established an inquiry into ethical standards following the disclosures concerning illegal phone hacking, and in Ireland the broadcasting regulator inquired into a documentary made by RTÉ following the libelling of a priest. So if there are problems in Western Europe following years of voluntary regulation, codes of conduct and legal regulation of broadcasters, why was it thought possible to change the media in the countries of the CIS/CEE with just a few short courses?

The UNICEF project described here succeeded because it did not specifically try to improve standards or ethics but instead dealt with these issues within the context of children's rights. Journalism students tend to be pragmatic: they attend university to gain the knowledge to do a specific job, and therefore want professors to impart whatever is necessary to ensure that outcome. This syllabus did not deal in abstract ideas of standards or ethical thinking but dealt specifically with that section of the population under the age of eighteen, and offered ways to develop stories and narratives that improved the visibility of children and addressed their rights. To do so, it was necessary to address a range of skills and knowledge areas. The syllabus also addressed the interdisciplinary nature of journalism education, suggesting the linking of journalism with not only media, law or even history, but - more radically - with those involved in rights education, early-childhood education and psychology. This method also addressed a problem at the heart of media development: Western journalism trainers going to show others in a sort of imperialist way how to do things. With this project, there was no suggestion that journalists in the West addressed issues surrounding childhood any better than their counterparts in the CIS/CEE countries. What was developed-possibly inadvertently — might provide a new model for media development.

\footnotetext{
${ }^{27}$ Raymond Allen Morrow and Carlos Alberto Torres, Reading Freire and Habermas: critical pedagogy and transformative social change (New York, 2002).
} 